\title{
30
}

\section{Individual Experience and Social Experience \\ as Sources of Religious Insight}

\section{I}

As we have defined religion, the main concern of any religion that we are to recognise is with the salvation of man, and with whatever objects or truths it is important to know if we are to find the way of salvation. Now the experiences which teach us that we need what I have ventured to call by the traditional name salvation, are, from my point of view, experiences common to a very large portion of mankind. They are great and, in certain respects at least, simple experiences. You can have them and estimate them without being committed to any one form of religious faith, without accepting any special creed about supernatural things, and even without hoping to find out any way of salvation whatever. The essential conditions for discovering that man needs salvation are these: You must find that human life has some highest end; and you must also find that man, as he naturally is, is in great danger of failing to attain this supreme goal. If you discover these two facts (and I personally hold them to be facts whose reality you can experience), then the quest for the salvation of man interests you, and is defined for you in

[Reprinted from SRI, pp. 37-75.] 
genuinely empirical terms. Given the problem, you may or you may not see how to solve it. You may or you may not appeal to what you suppose to be a revelation to guide you on the way. But in any case, granted these conditions, granted that your experience has shown you your need of salvation-then the problem of religion is upon your hands. Soluble or insoluble, the topic of a revelation from above, or of a scientific inquiry, or of a philosophy, or of a haphazard series of efforts to better your condition, this problem, if it once comes to hold your attention, will make of you a religious inquirer. And so long as this is the case, no degree of cynicism or of despair regarding the finding of the way to salvation, will deprive you of genuinely religious interest. The issue will be one regarding facts of live experience. The concerns that for you will seem to be at stake will be perfectly human, and will be in close touch with every interest of daily life.

To conceive the business of religion in this way simplifies our undertaking, in so far as it connects religion not merely with doubtful dogmas and recondite speculations, but rather with personal and practical interests and with the spirit of all serious endeavour.

Upon the other hand, this way of defining religion does, indeed, also complicate certain aspects of our present task. For if, from our point of view, religion thus becomes, in one way or another, the concern of everybody who has once seen that life has a highest goal, and that we are all naturally in great danger of missing this goal-still any effort to study the nature of religious insight seems to require us to be somehow just to all the endless varieties of human opinion regarding what the highest goal of human life is, and regarding the way to attain that goal after we have once defined it. In some sense, in our further inquiry, nothing human can be alien to us, in case it involves any deep experience of man's purpose in living, or of man's peril as a seeker after the attainment of his purpose; or any assurance regarding the presence or the power which, entering into some sort of union with any man's own spiritual life, seems to that man an apt Deliverer from his evil plight, a genuinely saving principle in his life.

How great the resulting complications that threaten our investigation seem to be the conclusion of our former lecture showed us. Countless souls, trusting to their individual experience, have learned, as we at the last time indicated, to define their ideal, and their need, and, upon occasion, to discover the power that they took to be their 
saving principle-their deliverer. Who amongst all these were right, either in their judgment as to their need or in their consciousness that they had found the way that leads to peace, to triumph, to union with the goal of human life? Were all of them more or less right? Were any of them wholly deluded? Are there as many supreme aims of life as there are individuals? Are there as many ways of salvation as there are religions that men follow? And by what means shall we decide such questions? Grave and infinitely complicated seem the issues which these queries arouse.

Upon one side, then, our problem is pathetically simple, human, practical, even commonplace. Daily experience, in serious-minded people, illustrates it. The plainest facts of our life exemplify it. It concerns nothing more recondite than that tragedy of natural human failure which you may constantly witness all about you, if not within you. Upon the other side, no questions more bring you into contact with the chaotic variety of human opinion, and with the complexities of the whole universe, than do the religious questions, when thus defined in terms of men's deepest needs and of men's hopes and faiths regarding the possible escape from their most pressing peril of failure.

Our first lecture gave us a glimpse of this simplicity of the main definition of our problem and of this complication with regard to the conflicting proposals that are made toward its special formulation and toward its solution. We have now to study further the sources of insight upon which every solution of our problem must depend.

\section{II}

Our present lecture will be devoted to three tasks. First, we shall try to show that the religious consciousness of mankind, when it is concerned with the need and with the way of salvation, must needs appear in many various and apparently conflicting forms, but that, nevertheless, these conflicts need not discourage us. For, as we shall attempt still further to explain, the underlying motives of the higher religions are, after all, much more in agreement than the diversities of creeds and the apparent chaos of religious experiences would lead us to imagine. In order to make this deeper unity of the higher religious life of mankind plain, we shall try to show, more fully than we did in the last lecture, how the consciousness of the 
ideal of life, and of the need of salvation, naturally arises in the experience of the individual man. The religious paradox, as, in our former lecture, we defined that paradox, depends upon the fact that the principal religious motives are indeed perfectly natural and human motives, which need no mysterious movings from another world to explain their presence in our lives; while, on the other hand, these very motives, when once they appear, force us to seek for relief from spiritual sources that cannot satisfy unless they are far above our natural human level of life-that is, unless they are in some definable sense superhuman. But about superhuman matters it is not surprising that ignorant mortals should widely differ, despite the deeper unity that underlies all our nobler religious needs.

Thus the unity of the religious concerns of mankind is perfectly compatible with the fact that men differ so widely in faith. The mysteries of religion belong to our natural failure to conceive readily and to grasp adequately the religious objects. But our religious need is not a mystery; and our religious interests are as natural as is our ignorance. The higher forms of the religious consciousness are due to perfectly human motives but lead to a stubborn quest for the superhuman. To understand whence the higher religions get their moving principle, you have only to survey our natural life as it is, in all its pathetic and needy fallibility. But if the higher religions are to find what they seek, they call for sources of insight which you cannot define, unless we are able to know a reality that transcends human nature as it is-unless we can come into genuine intercourse with a spiritual realm that is above man. This naturalness of the religious motives, this supernatural and naturally baffling character of the religious objects, I am, then, first to illustrate still further than I at the last time was able to do.

I shall thus be led, in the second place, to the mention of that source of religious insight to which, at the close of the former lecture, I directed your attention, namely, to our social experience. Society, in a certain sense, both includes and transcends the individual man. Perhaps, then, something can be done toward solving the problem of the religious paradox, and toward harmonising the varieties of religious opinion, by considering the religious meaning of our social consciousness. The religious paradox is that the needy and ignorant natural man must somehow obtain the spiritual power to get into a genuine touch with a real life that is above his own level. If he is to be saved, something that is divine must come to be 
born in the humble manger of his poor natural life. How is this apparition of the divine in the human, of the supernatural in the natural, conceivable? It is that question which most of all divides men into various religious sects. Perhaps a study of our social experience, which, indeed, often tends to mould our naturally narrow selfishness into nobler spiritual forms, may throw light upon this problem. And so I shall, in this second part of the present discourse, state the case for our social experience as a source of religious insight.

We shall, however, no sooner state this case than we shall begin to see how inadequate our ordinary social experience is to give us full religious insight. Therefore, in the third place, I shall try to estimate more critically both the merits and the imperfections of this second source of religious light, and thus I shall be led, as I close, to the mention of a third source, from which, as I hold, we can learn what neither our unaided private experience nor our ordinary social experience ever adequately shows.

\section{III}

Let me proceed at once to the first of these three undertakings. I am further to illustrate, on the one hand, the unity and the naturalness of the religious motives; on the other hand, I am to emphasise the mysterious seeming of the religious objects. And I am thus to show the reason why the faiths of men are so diverse but their religious needs so nearly common.

At the last time I tried to define for you, in my own terms, what the supreme purpose of human life is, or, in other words, what that highest good is which we are all in such peril of missing that we need salvation from this peril. My definition was this: We are naturally creatures of wavering and conflicting motives, passions, desires. The supreme aim of life is to triumph over this natural chaos, to set some one plan of life above all the others, to give unity to our desires, to organise our activities, to win, not, indeed, the passionless peace of Nirvana, but the strength of spirit which is above the narrowness of each one of our separate passions. We need to conceive of such a triumphant and unified life, and successfully to live it. That is our goal: Self-possession, unity, peace, and spiritual power through and yet beyond all the turmoil of life-the victory that overcometh in the world. 
Now this definition of the ideal life will have seemed to some of you too much a merely philosophical formula. You will say that this is not what plain men have in mind when they ask God's help, or lament their sins, or look to religion for consolation.

I grant you that, since I am here concerned with philosophy and not with preaching, I, of course, prefer, for my present purpose, a formulation of the ideal of life in reflective, in thoughtful terms. But I cannot admit that plain men, in their religious moods, are not concerned with the ideal of life which I thus reflectively formulate. I am trying to formulate the ideal of life that seems to me to underlie all the higher religions. It is one thing, however, to feel an interest and another thing to become conscious of the meaning of the interest. No matter how inarticulate may be a man's sense of his need, that sense, if deep and genuine, may imply a view of life which a whole system of ethics and of metaphysics may be needed to expound. Philosophy ought to be considerate, and to use more or less technical speech, but it need not be on that account inhuman. Its concern is with what common-sense means but does not express in clearly conscious terms. It does not want to substitute its formulas for life. It does desire to add its thoughtfulness to the intensity of life's great concerns and to enlighten us regarding what aims life has always really intended to pursue.

My own effort to formulate the supreme end of life does not seem to me to be foreign to common-sense. I think that this way of stating the purpose of life may help us to see through many of the apparently hopeless diversities of human opinion regarding what the highest good is.

It is customary to describe that longing for salvation which is, from the point of view of these lectures, the foundation of religion, by saying that the man who begins to get religious interest discovers that when left to himself he is out of harmony with what James calls "the higher powers," that is, with what a Christian calls God. In other words, as a customary formula states the case, the religiously disposed man begins by learning that the chief end of his existence is to come into harmony with God's will. And this discovery, as such a view supposes, teaches him, for the first time, what his ideal of life ought to be. And therefore, as many say, something that is of the nature of a mysterious revelation from without is needed to initiate the religious process and to show us our goal. On the other hand, writers like James, who insist upon interpreting 
religion, so far as that is possible, in terms of personal experience rather than in terms of external revelation, have nevertheless been led to agree with many of the partisans of revelation in regarding this sense of our disharmony with the "higher powers" as something that must have an essentially superhuman source. For James, our sense of religious need is an experience which mysteriously wells up from the subliminal self, from the soundless depths of our own subconsciousness. James, therefore, conceives it probable that, through the subliminal or subconscious self, we are actually aroused to religious interest by spiritual beings whose level is higher than our own, and whose will, expressed to us through the vague but often intense sense of need which the religiously minded feel, does set for us an ideal task which is of greater worth than our natural desires, and which, when we can get into harmony with these powers through the aid of their subliminal influences, does give a new sense to life.

Now in contrast with such views regarding the origin of that deeper sense of need which is indeed the beginning of religion, I have to insist that the basis of the religious interest is something much less mysterious than James's supposed workings of the "higher powers" through our subliminal selves, and is also something much more universally human than is the opportunity to come under the influence of any one revelation. Men who never heard of Christianity, and men who have never felt conscious of any external revelation from above, as well as men who have had no such sudden uprushes from their own subconscious natures as James's "religious geniuses" have reported, are able to win a genuine religious interest, to be aware of an intense need for salvation, and to set before themselves, in however inarticulate a fashion, the very ideal of life which I have been trying in my own way to formulate. The need and the ideal can come into sight in a manner that indeed does not in the least either exclude or require a belief in one or in another reported revelation, but that links both the need and the ideal to our ordinary personal experience by ties which are not at all mysterious. Let me show you, then, better than my time permitted in the former lecture, how an individual may naturally experience what I have called his need of salvation.

Nothing is more obvious about the natural course of our lives than is the narrowness of view to which we are usually subject. We are not only the victims of conflicting movies, but we are often 
too narrow to know that this is true. For we see our various life interests, so to speak, one at a time. We forget one while we are living out another. And so we are prone to live many lives, seldom noting how ill harmonised they are. Home life, for instance, may be one thing; business life in principle another; sport or social ambition another. And these various lives may be lived upon mutually inconsistent plans. We forget one part of ourselves in our temporary absorption in some other part. And if, as our naturally complex and often conflicting motives determine, these our various lives are out of harmony with one another, we constantly do irrevocable deeds that emphasise and perpetuate the results of this disharmony. And as we grow older our motives alter; yet because of our natural narrowness of interest, we often do not recognise the change. Our youth consequently lays a poor foundation for our age; or perhaps our mature life makes naught of the aspirations of our youth. We thus come to spend a great part of our days thwarting ourselves through the results of our fickleness, yet without knowing who it is that thwarts us. We love, and, like Siegfried, forget our former beloved, and perhaps live to feel the fatal spear-thrust that avenges our treason to our own past. The deeper tragedies of life largely result from this our narrowness of view.

But over against this narrowness of our ordinary activities there, indeed, stand certain moments when we get a wider vision of ourselves, when we review life, or foresee it with a broad outlook. These are, indeed, moments of insight. We all know how tragic they often are, because they show us at a glance how with the left hand we have undone the right hand's work, how we have loved and forgotten, how we have sworn fealty to many masters, and have cheated one while we served another, how absorption in business has made us unworthy of home, or how we have wantonly sacrificed a friend in order to win a game, or gained our bit of the world through what, upon review, we have to call the loss of our souls. Such moments of insight come to us sometimes when our friends die, and when memory reminds us of our neglected debts of love or of gratitude to them, or when worldly defeat reawakens the long-forgotten unworldly aspirations that we abandoned in order to do what has ended in earning the defeat. These are, I repeat, often tragic moments. But they enlighten. And they show us our need. And they arise as naturally as does any other incident of a reasonable life. 
What need do they show? I answer, the need to possess what by mere nature we never come to possess, namely, the power to "see life steadily and see it whole," and then to live triumphantly in the light of this vision. Can a plain man who is no philosopher feel this need? I answer, Yes, whenever he has his moments of vision; whenever he feels the longing for the clean, straight, unswerving will, for the hearty whole life; whenever he sees and regrets his fickleness, just because it means self-defeat; whenever he seeks to be true to himself. At such moment his highest aim is the aim that there should be a highest aim in life, and that this aim should win what it seeks. He has the longing, however inarticulate, for integrity of spirit and for success in winning the fruits of integrity.

When the plain man feels what I venture thus to formulate, how will he express his longing? He will, of course, not use my present formulas. He will seize upon whatever expressions the creed or the language of his tribe may suggest to him. He may say, and perhaps truthfully: "This is the ideal that God sets before me. This is the divine will regarding my life." For at such times he conceives of God as the being who has widest vision and who knows him best. Therefore he conceives of God's plan as the fulfilment of his own rational plan. But the interior source of the plain man's view regarding the divine will is simply his better vision of the meaning of his life, the vision that comes at moments when he is not forgetful of the whole; when he does not want to swear fidelity to one beloved, and then, like Siegfried, pursue and win another; when he wants to be true to the whole of himself. No wonder that he, indeed, conceives this supreme goal of life as the goal set for him by some will higher than his own private will. $\mathrm{He}$ is right. For, as we shall see, throughout our later study, we are, indeed, helpless either to hold before us this our personal vision of the triumphant life and of the unity of the spirit, or to turn the vision into a practical reality, unless we come into touch and keep in touch with an order of spiritual existence which is in a perfectly genuine sense superhuman, and in the same sense supernatural, and which certainly is not our natural selves.

But in any case the plain man must needs interpret his vision of the ideal in terms of whatever conception of God, or of the triumphant life, or of spiritual power, his traditions and his stage of personal development may suggest to him. Hence the endless varieties in the formulation of the religious ideal. Whatever is suggested 
to a man, at his moments of wider vision, as a law or as a motive which, if it were the ruling motive or the supreme law would make life a consistent whole-this he takes to be God's will, or the truth that is to save him if, indeed, salvation is possible.

If this account of the sources of the religious motive is right, we need not view the religious interest as the result of an arbitrary intrusion from above-as if the gods loved to disturb us and to trouble our peace. Nor need we, with James, speak of a marvellous and capricious uprush from below the level of our natural consciousness. Yet just as little need we think of religion as having no concern with what is, indeed, superhuman. Religion is, indeed, our own affair; for it grows out of our personal vision of the transformation that a divinely enlarged power to comprehend, to survey, to harmonise, to triumph over our natural life would give. This vision comes to us at moments, in glimpses-and is seen through a glass darkly. Our need is to see face to face and to live in the light thus to be discovered. And so to live would be salvation. The word salvation is fitting, because the need is so great and because the transformation would be so profound. The endlessly various interpretations of this one ideal and of the nature of the saving process are due to the wealth of life and to the imposing multitude of motives and of experiences that the religious consciousness has to consider. But beneath and above all the varieties of religious experience lies the effort to win in reality what the vision of the harmonious and triumphant life suggests to us in our moments of clearness. Since our own natures leave us hopelessly remote from this goal, while our glimpses of spiritual harmony and power reveal to us its preciousness, our religious need is supreme, and is accompanied with the perfectly well-warranted assurance that we cannot attain the goal unless we can get into some sort of communion with a real life infinitely richer than our own-a life that is guided by a perfect and unwavering vision, and that somehow conquers and annuls all fickleness, conflict, and estrangement. Such a life rightly seems to us to be superhuman in its breadth of view and in its spiritual power, if indeed there be such a life at all. If there is no such life, none the less we need it, and so need salvation. If salvation is possible, then there is in the universe some being that knows us, and that is the master of life. And we seek ourselves to know even as we are known and to live as the wise one would have us live.

Thus simple and, for all to whom even the occasional moments of 
wider vision come, universal are the religious motives. James was wrong when he sought them in any capricious interference of the subliminal self, or of its superhuman controls, with our natural selves. It is we who in our natural lives are capricious and narrowly interfere with our own freedom. It is we who are the disturbers of our own peace. The religious ideal grows out of the vision of a spiritual freedom and peace which are not naturally ours. No two of us get that vision in quite the same way. But all its forms show us the same far-off shining light. The problem of religious insight is the problem whether that light is a mirage.

No wonder, then, that men differ as to their special efforts to solve such a problem. But it is now our task to seek for further sources of insight.

\section{IV}

The foregoing discussion may seem to have led us far from the study of our social experience as a source of religious insight. But in fact it is a necessary preliminary to that study and leads us very near to it.

If one principal source of our need of salvation is the natural narrowness of our view of the meaning of our own purposes and motives, and the consequent fickleness and the forgetful inconsistency with which we usually live out our days, it seems right, in searching for a way that may lead toward salvation, to get such help as we can by looking to our normal social experience for whatever guidance it can give. The social world is wide, even if it is still full of conflict. It broadens our outlook at every turn. A man corrects his own narrowness by trying to share his fellow's point of view. Our social responsibilities tend to set limits to our fickleness. Social discipline removes some of our inner conflicts, by teaching us not to indulge caprices. Human companionship may calm, may steady our vision, may bring us into intercourse with what is in general much better than a man's subliminal self, namely, his public, his humane, his greater social self, wherein he finds his soul and its interests writ large. Perhaps, then, whatever the ultimate goal, the way out of the distractions of the natural self, the way toward the divine insight and power that we need, lies through our social experience.

No wonder, then, that in the religious discussions of to-day our social experience is that source of insight upon which a great num- 
ber of our teachers, whether they are professional religious teachers or not, most frequently insist. Our present time is an age of great concern with social problems and reforms. No wonder, then, that we have all learned to widen our vision, and to control our waywardness, by remembering that man is a being who can be neither understood nor directed in case you try to view him in isolation. As for salvation, many of our most influential leaders now teach us that the problem of our day is the problem of saving, not the individual as an individual, but the social order as a whole. The two tendencies which seem to be most potent in the political realm are the general tendencies known by the admittedly vague names of democracy and socialism. Solidarity, collectivism, the common life-these are the watchwords of some of the most widely influential movements of our time.

And these watchwords have, for many of us, not only a political, but a religious meaning. I need not remind you of the popular influence of such dramas as "The Servant in the House," or of the numbers of clergymen to whom the preaching of religion has come to mean, in the main, the preaching of beneficent social reforms. If teachers who thus view religion as, on the whole, a movement toward the increase of social welfare are asked what their counsel is to the individual regarding the salvation of his soul, they will reply: "If you want to be saved, come out of yourself." Some of them would add: "Forget yourself." But whether they use this latter extremely ambiguous and doubtful form of advice, they very generally agree that to seek to save your own soul by any merely or mainly inward and non-social process is to secure perdition. "It is love that saves," they are fond of telling us. And in this doctrine, as interpreted in the light of our modern social movements, many see the entire essence of Christianity adapted to our present situation.

Nor is the tendency here in question limited to the practical counsels of which I have just reminded you. There are those students of the psychology and the philosophy of religion who are disposed to conceive that the whole essence of the religion of all times, the entire meaning of religious beliefs and practices, can be exhaustively and accurately described in the purely human and social terms which these practical counsels attempt to embody. A recent writer on the psychology of religion defines religion as man's consciousness of his highest social values, and maintains that all religious beliefs 
are attempts to express this consciousness in whatever terms a given stage of civilisation makes natural and possible.

One can easily suggest to any student of general history some of the facts which such a writer has in mind. Have not the gods often been conceived as tribal deities, and so simply as representatives of the welfare and of the will of the community over against the waywardness and the capriciousness of the individual? Was not the transition from polytheism to the various forms of pantheism and of monotheism determined by the social processes that formed kingdoms or empires, and that finally led over to the modern appreciation of the value of the common interest of an ideally united humanity? Were not the prophets of Israel social reformers? Was not the work of Jesus an anticipation and a prophecy of the coming consciousness of the brotherhood of man, as the lovers of mankind now conceive that brotherhood? What has religion had to teach us, some will insistently ask, more saving, unifying, sustaining, than this love of man for man?

From such a point of view, as you see, our social experience is our principal source of religious insight. And the salvation that this insight brings to our knowledge is salvation through the fostering of human brotherhood. Such salvation accrues to the individual so far as he gives himself over to the service of man, and to mankind in so far as men can only be saved together and not separately.

I am just now depicting, not judging, a view concerning the solution of religious problems which you know to be, in our day, as potent as it is varied and problematic in its teaching. Can this view satisfy? Does this way of stating the case really indicate to us any adequate source of religious insight, any way in which we can define the true salvation of man?

\section{$\mathbf{V}$}

We cannot answer this question without taking account of the views of those of our recent teachers to whom this purely social theory of the religious objects and values is indeed profoundly unsatisfactory. That such opponents of the adequacy of the interpretation of religion just suggested are to be found amongst the believers in familiar religious traditions, we need not at any length set forth. The traditions of the great religions of the world do not interpret the old 
faiths in this way, just because these religious traditions all agree in regarding the human social order as something which exists for the sake of an essentially superhuman order. As these various faiths assert, man can never be saved by purely human means, whether you call these means preventive medicine, or socialism, or universal brotherhood, or even love, so long as love means simply human love. As for Christianity, in all its older forms, it has emphasised the love of man, but always in a certain union with the love of God which tradition could never conceive as adequately expressible in terms of our recent social movements. The "Servant in the House" is supposed to be a modern apparition of the Christ; but he is explicitly a heretic regarding the old faith of the church.

But with tradition as tradition, these lectures have to do only by way of occasional illustration. What interests us more, for our present purpose, is the fact that, despite the predominance of the social interpretations of religion of which I have just reminded you, there are still some of our recent teachers who stoutly insist that our secial experience does not adequately show us any way of salvation whatever.

And here first I must call attention to certain of the most modern and least theologically disposed of our leaders, namely, to those who emphasise the most characteristic recent forms of individualism. I have mentioned Nietzsche in my former lecture. Surely he stands for opposition to tradition and he expresses tendencies that are potent to-day. But while he lived and wrote, he aspired to be a sort of Antichrist, and preached the doctrine that a religion of love can never save, because, as he insists, what the self needs is power, and power is not to be won by attempting to please a world of slaves. Nietzsche may seem to you, as he has seemed to so many, a hopeless abnormity; but his Titanism is in fact a wayward modern expression of a motive that has always played its notable part in the search for salvation, ever since heroism and the resolute will were first discovered by man. Nietzsche's insight too, such as it is, is a social insight. It comes through noting that, even if the individual needs his social world as a means of grace and a gateway to salvation, the social order, in its turn, needs individuals that are worth saving, and can never be saved unless it expresses itself through the deeds and the inner life of souls deeply conscious of the dignity of selfhood, of the infinite worth of unique and intensely conscious personal life. 
As a fact, individualism is as potent an ethical motive in the life of to-day as is the collectivism just characterized. Each of these tendencies, in our present social order, feeds upon and intensifies the other. Socialism opposes, and yet inevitably encourages, the purposes of the very individual who feels his social ties as a galling restraint. It preaches solidarity and brotherhood and love; but wins a ready hearing from those who view all these tendencies mainly as means whereby they may hope to have their own way, and to become, as Nietzsche's Superman, "beyond good and evil"masters in the coming world of triumphant democracy. The social experience of our time is full of ambiguous lessons. Its way toward salvation leads not only over the Hill of Difficulty, but both ways around the hill; and it shows us no one straight and narrow road to peace. Whoever would traverse its wilderness and reach salvation needs to supplement his social insight by a use of other and deeper sources.

And as to what these deeper sources of insight are, the teacher whom I have already repeatedly cited-William James-asserts a doctrine that, as you already know, I do not regard as adequate, but that I must again here emphasise, because its contrast with that social theory of religion which I just characterised is so instructive. James, in his "Varieties of Religious Experience," shows the utmost liberality toward differences of faith, and insists in the opening chapters of his book that religious experience is a field where one must beware of defining sharp boundary lines or of showing a false exclusiveness. Yet one boundary line he himself defines with the greatest sharpness; and in respect of one matter he is rigidly exclusive. Religious experience, he insists, is, as you will remember from our first lecture, the experience of an individual who feels himself to be "alone with the divine." And the social types of religious experience James rigidly excludes from the "varieties" whereof he takes account. And James's reason for this procedure is explicit. In its social aspects religion, so he insists, always becomes, or has already become, conventional. James no longer finds in the religious life of communities the novelty and independence of vision which he prizes. The essence of true religious experience lies, for him, in its originality, in its spontancity, and so in the very solitude which is a condition, to James's mind, for the discovery of that which saves.

The words "originality" and "spontaneity" emphasise the features which, as I think, James most meant to emphasise. The prob- 
lem of salvation, for James, must be an essentially individual problem; for nobody else ever faced your need of salvation, or had your personal issues to meet. If you win religious insight, you will have to win it very much as you will have to die-alone. Of course James does not hesitate to test the value of religious experience, in his pragmatic fashion, by its social as well as by its individual consequences. The fruits of the spirit accrue to the general advantage; and the saint, in James's opinion, must indeed undertake to edify, not only himself, but also his brethren. But the effects of religious insight must not be confused with the sources. James insists that the sources are mainly from within the individual and are only incidentally social. A religious discovery has in common with a poetic creation the fact that the religious genius, like the artist, sees his vision, and produces his spiritual miracle, in solitude.

If you ask whether this position which James assumes is anything more than his own private opinion, and if you want to know his grounds for it, a closer examination of his book will show you why he thus deliberately turns his back upon the favourite recent interpretation of religion as an essentially social phenomenon. James, in common with the traditional faiths, although not in conformity with their formulas, always conceived religious experience as an intercourse with objects and with powers that, whatever their deeper bases in our "subliminal" nature, do not adequately express themselves in our everyday, worldly, overt human nature. And in our social life, where the conventional reigns, where man imitates man or contends with man, where crowds bustle and the small-talk or the passionate struggle of the day fill the mind, where lovers pursue their beloved and are jealous of their rivals, and laborers toil and sweat, and worldly authorities display their pomp, you meet not the solution, but the problem of life. James, as man, was full of social interests, and, as psychologist, was fond of studying social processes. But when a man wants peace and spiritual triumph, James observes that, as an empirical fact, he does not readily find them in the market-place, or on the battle-field, or in the law courts, unless, indeed, he comes to these places already full of the light that the saintly souls have often found in the wilderness or in their meditations. In brief, James always emphasises the mystical element in religious experience and is full of the assurance that religion cannot find its food in the commonplace; while our social life is a realm 
where the commonplace holds sway. Or again, James holds that when the faithful have thought of their religious experience as an intercourse with beings of a level wholly superhuman, they may, indeed, have been wrong in their creeds, but were right in holding that man as he lives in his social world can never save man. Our social consciousness is too barefaced and open in its union of triviality and pathos. What we want as the saving power is, for a teacher such as James, something more mysterious, deep, subconscious or superconscious, and in this sense, indeed, superhuman.

Still I am only depicting, not yet judging. I have now briefly stated opinions that favour and opinions that oppose an interpretation of religious insight in terms of our social experience. But what are the merits of the case? In what sense can there be a religion of the social consciousness?

\section{VI}

The answer to this question involves, I think, two considerations, both of them exemplified by the various views here in question, both of them familiar, both of them easily misinterpreted. The first is the very consideration upon which our popular teachers of salvation through love most insist. We ourselves came upon that consideration at the close of our first lecture. Man is, indeed, a being who cannot be saved alone, however much solitude may help him, at times, toward insight. For he is bound to his brethren by spiritual links that cannot be broken. The second consideration is this: So long as man views his fellow-man merely as fellow-man, he only complicates his problem, for both he and his fellow equally need salvation. Their plight is common; their very need of salvation chains them together in the prison of human sorrow. If, to adapt the symbolism of ancient stories to our case, the angel of love is to appear in their prison, is to loosen their chains, is to open the doors, it must be, in some wise, as an angel, not as a merely human presence, that love must appear.

Perhaps the best way to indicate wherein lies the strength and the weakness, the irresistible authority and the pathetic limitation of our social experience as a religious guide, and the best way also to indicate its true relations to the religious experience of the human individual, is to remind ourselves of a very few familiar cases in 
which an individual finds that his own way toward salvation, if any such way is to exist for him at all, lies through his social world, so that he cannot be saved without the help of his fellows.

Our first instance shall be an extreme one, in which the sense of need is intense and the longing for salvation acute, but where there is little or no hope of finding the way, although one knows that if the way could be found it would bring one into touch with a new type of human companionship. We all know how the sense of guilt may take the form of a feeling of overwhelming loneliness. Now the sense of guilt, if deep and pervasive and passionate, involves at least a dim recognition that there is some central aim of life and that one has come hopelessly short of that aim. I may regret a blunder, and yet have no hint that there is any unified and supreme ideal of life. For a blunder is a special affair involving the missing of some particular aim. I may even bitterly repent a fault, and still think of that fault as a refusal to pursue some one separate moral purposea violation of this or of that maxim of conduct. But the true sense of guilt in its greater manifestation involves a confession that the whole self is somehow tainted, the whole life, for the time being, wrecked. But the bankruptcy of the self implies that there is one highest purpose which gives the self its value; the sense of total failure is itself a revelation of the value of what was lost. Hence the highly idealising tendency of the great experiences of moral suffering. They lead us to think not of this or of that special good, but of salvation and perdition in their general bearing upon life. The depth of the despair shows the grandeur of what has been missed; and it is therefore not surprising that experiences of this sort have been, for so many, the beginnings of religious insight. To believe that one is cut off from salvation may be the very crisis that in the end saves.

Now some of those who feel this overmastering might of their guilt lay most stress upon their assurance that God has condemned them. And religious tradition has of course emphasised this way of stating the case. But it is perfectly natural, and is surely a humane experience, to feel the sense of guilt primarily in the form of a belief that one is an outcast from human sympathy and is hopelessly alone. The more abnormal types of the sense of guilt, in nervous patients, frequently exemplify this terror of the lonely soul, this inner grief over the homelessness of the remorseful outcast. But actual guilt may be present with or without the more abnormal 
nervous conditions just mentioned, and, when present, may bring home to the rueful mind the despair of the awakened but forsaken sinner, and may bring it in the form of the feeling of guilty solitude.

A well-known expression of such a mood you find in Kipling's lyric of the "Poor little sheep that have gone astray." In these verses the outcast sons of good families, the "gentlemen-rankers," dwell together in an agonised companionship of common loneliness. Their guilt and their lost homes are for them inseparably associated.

Or again: Beneath all the fantastic imagery of Coleridge's "Ancient Mariner," the poet uses a perfectly recognisable type of the sense of guilt as the means to make his tale of wonders seem, despite all its impossibilities, human and even plausible. The incidents are the miracles of a magic dream; but the human nature depicted is as real as is the torment of any guilty conscience. Somehow-no matter how, or under how arbitrary conditions-the hero has committed a crime without precisely intending it to be a crime. His tale is one of a young man's adventurous insolence. His deed has all the too familiar characters of the typical sins of wayward youth. And that is why the gay young wedding guest must hear his tale. Hethe mariner-in his own youth, had consciously meant to be only a little wanton and cruel. He awakened, as many a light-minded youth later awakes, to find that, as a fact, he had somehow struck at the very centre of life, at the heart of love, at the laws that bind the world together, at the spirit of the universe. When one thus awakes, he sees that nature and God are against him. But, worst of all, he has become a curse to his fellows; and in turn they curse him; and then they leave him alone with the nightmare life in death of utter solitude. To his mind there are no living men. He sees about him only "the curse in a dead man's eye." What life he can still see is no longer, to his morbid eyes, really human:

The many men, so beautiful!

And they all dead did lie;

And a thousand, thousand slimy things

Lived on; and so did I.

The Ancient Mariner's escape from the horrors of this despair, the beginnings of his salvation, date from the first movings of love in his heart toward all living beings. His salvation is won when, at the end, he finds God along with the goodly company at the kirk. In brief, the curse of his guilt is to be "alone on a wide, wide sea." 
His salvation comes in preaching love and companionship, and in uniting himself hereby to the God who loves all things both great and small.

Now one does not often think of the "Ancient Mariner" as a poem of religious experience; but apart from its brilliant play with natural magic, its human charm actually depends upon this wellfounded picture of the loneliness of guilt and of the escape through loving union with one's kind. And the poet deliberately gives to this picture the form and the sense of a religious process of salvation.

If you turn from the dreamy product of Coleridge's youthful fancy to the opposite pole of modern literature, you find an instance of almost the same motives at the basis of that most impressive romance of the Russian Dostoieffsky: "Crime and Punishment." Dostoieffsky had himself lived long in what he called "The House of the Dead," in Siberia, before he learned how to write this masterpiece. He had been forced to sojourn amongst the guilty of the most various grades. He had come to universalise their experiences and to struggle himself with one form of the problem of salvation. Those who, like Dante, have looked upon hell, sometimes have, indeed, wonders to tell us. Dostoieffsky condenses the whole problem of salvation from guilt in this picture of an individual. Raskolnikow, the hero, after his thoughtfully conceived crime, and after his laborious effort at self-justification, finds himself the prey of a simply overwhelming sense that he walks alone amongst men, and that, in the crowded streets of the city, he is as one dead amongst spectres. There is nowhere, I think, a more persuasive picture of the loneliness of great guilt. Raskolnikow could not be more the victim of supernatural forces if he were Coleridge's Ancient Mariner. Like the Ancient Mariner, Raskolnikow in the end finds the way to salvation through love-the love which the martyred Sonia teaches him-herself, as our Russian most persuasively pictures her, at once outcast and saint. The author uses religious conceptions which are both ancient and, in his use of them, unconventional. But the central one of these is the familiar conception that salvation involves a reconciliation both with the social and with the divine order, a reconciliation through love and suffering-an escape from the wilderness of lonely guilt to the realm where men can understand one another.

In such elemental ways the process of salvation can be made to appear as essentially a social process, just because its opposite, perdition, seems to mean banishment from amongst men. 
Another group of cases presents to us the same need for human companionship as a means to salvation, but presents it in the winning guise of salvation beginning through love, without the main stress being laid upon the previous despair. In such cases the despair may be mentioned but at once relieved. The religion of friendship and of love is a familiar human experience. James, in his fear of debasing religion by romantic or by grosser associations, unjustly neglects it in his study of "varieties." In fact, to seem to find the divine in the person of your idealised friend or beloved is a perfectly normal way of beginning your acquaintance with the means of grace. You meet, you love, and-you seem to be finding God. Or, to use our present interpretation of what reveals the divine, love seems to furnish you with a vision of a perfect life, to give you a total survey of the sense of your own life, and to begin to show you how to triumph. If there be any divine life, you say, this is my vision of its beauty and its harmony. So the divine appears in one of Browning's later lyrics.

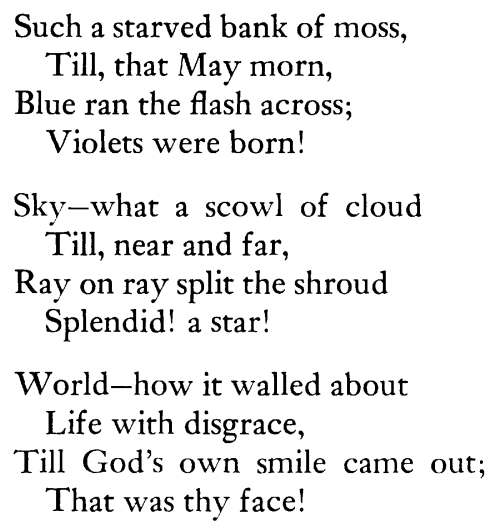

In the sonnets of Shakespeare this religion of friendship has found some of its most perfect expressions.

Haply I think of thee, and then my state, Like to the lark's, at break of day arising From sullen earth, sings hymns at heaven's gate.

And again, in Mrs. Browning's "Sonnets from the Portuguese," the religion of love not only uses speech intensely personal, fond, intimate, but also, and deliberately, accompanies all this with words derived from reflective metaphysics, or from theology, and intended 
to express the miracle that the nearest movings of affection are also a revelation of the highest powers of the spiritual world.

How do I love thee? Let me count the ways.

I love thee to the depth and breadth and height

My soul can reach, when feeling out of sight

For the ends of Being, and Ideal Grace.

I love thee to the level of everyday's

Most quiet need, by sun and candle light.

I love thee freely, as men strive for Right;

I love thee purely, as they turn from Praise;

I love thee with the passion put to use

In my old griefs, and with my childhood's faith;

I love thee with a love I seemed to lose

With my lost saints, -I love thee with the breath,

Smiles, tears, of all my life!-and, if God choose,

I shall but love thee better after death.

Surely one could not better express, than this sonnet does, the naturalness of the religious motive-the mystery of the religious object.

And finally, turning from these cases to those which are social in the larger sense, every patriotic song which deifies one's country, every other form of the religion of patriotism, exemplifies the experience of the devoted lover of his country by teaching that it is "man's perdition to be safe" in case his social world calls for the sacrifice of his life, and that salvation comes through service.

James is indeed wrong then to neglect the social roads that lead toward the experience of what one takes to be divine. There is no love so simple-minded that, if it be true love, the way of salvation may not seem to be opened through it to the lover.

But observe that, as we review these instances, they show us how the social world wherein they bid us seek our salvation is a world whose very essence is transformed by love and by its vision into something that seems to the lover mystical, superhuman, and more than our literal and commonplace social life directly exemplifies. Those who have failed to find in their actual social life such inspirations may, indeed, have to look, as the typical mystics have generally done, elsewhere, for their vision of the divine, than in so much of the social world as they know. And such will, indeed, seek their vision of salvation in solitude. When they tell us of their experience, they may well remind the social enthusiast, as well as 
the lover, that the religion of love is no religion at all, unless it conceives its human object not only as this creature, or as this collection of needy men and women, but as a hint, or revelation, or incarnation of a divine process-of a process which is not only human but superhuman, and which can never be comprehended in the "mart and the crowded street" unless by the soul that is either mystical enough to meet God also "in the bush," or rationally enlightened enough to know that human life is indeed a revelation of something that is also superhuman.

I conclude, then, for the moment, thus: Social experience seems to lie on the way to salvation. Normally the way to salvation, if there be any such way, must lead through social experience. But when our social experience shows us any such way upward it does so, if it truly does so, because human social life is the hint, the likeness, or the incarnation of a life that lies beyond and above our present human existence. For human society as it now is, in this world of care, is a chaos of needs; and the whole social order groans and travails together in pain until now, longing for salvation. It can be saved, as the individual can be saved, only in case there is some way that leads upward, through all our turmoil and our social bickerings, to a realm where that vision of unity and self-possession which our clearest moments bring to us becomes not merely vision, but fulfilment, where love finds its own, and where the power of the spirit triumphs. Of such a realm the lovers dream and the religions tell. Let us appeal to a further source of insight. Concerning the realities that we need, let us next consult our Reason. 
